\title{
The Leave of Court Requirement for Instituting \\ Derivative Actions in the UK: A Ten-Year \\ Jurisprudential Excursion
}

F Hamadziripi* and PC Osode ${ }^{\star *}$

\section{P.E.R}

Pioneer in peer-reviewed,

open access online law publications

Authors

Friedrich Hamadziripi

Patrick C Osode

Affiliation

University of Fort Hare

South Africa

Email

FHamadziripi@ufh.ac.za

POsode@ufh.ac.za

Date Submission

23 August 2020

Date Revised

8 March 2021

Date Accepted

8 March 2021

Date published

29 March 2021

\section{Editor Dr N Kilian}

How to cite this article

Hamadziripi F and Osode PC "The Leave of Court Requirement for Instituting Derivative Actions in the UK: A Ten-Year Jurisprudential Excursion" PER / PELJ 2021(24) DOI

http://dx.doi.org/10.17159/1727-

$3781 / 2021 / v 24 i 0 a 8824$

Copyright

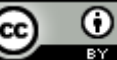

DOI

http://dx.doi.org/10.17159/1727-

$3781 / 2021 / v 24 i 0 a 8824$

\begin{abstract}
The judiciary-exclusive role to allow or deny the commencement or continuation of contemporary derivative litigation is one of the critical aspects of such proceedings. Before the 2006 codification, derivative actions were brought under the common law as exceptions to the rule in Foss $v$ Harbottle (1843) 67 ER 189. However, after realising intolerable deficiencies in the common law, the United Kingdom Law Commission (the Law Commission) recommended that there should be a new derivative procedure that met modern demands. This resulted in a statutory derivative remedy which can be activated in terms of Chapter 1 of Part 11 of the Companies Act, 2006 (United Kingdom). The effectiveness of legislative regulatory devices generally, and commercial law-related ones in particular, may to a greater extent depend on judicial interpretation and application. A conservative and literal interpretive approach that is purpose-neutral will significantly undermine the prospect of the current derivative remedy regime's achieving the intended policy objectives. To that end, this contribution examines several court decisions handed down after the enactment of the 2006 Act and spanning over a period of approximately ten years. Ultimately, it will be considered whether the leave requirement in English derivative litigation is proving to be an invaluable and indispensable procedural prerequisite or an implausible barrier to honest litigants.
\end{abstract}

\section{Keywords}

Derivative litigation, leave of court, judicial attitude, jurisprudential excursion, United Kingdom. 


\section{Introduction}

One of the key aspects of contemporary derivative litigation in the United Kingdom (UK) is the role played by the courts in allowing or denying the commencement or continuation of such legal proceedings. Before their 2006 codification, derivative actions were instituted under the common law ${ }^{1}$ as exceptions to the rule in Foss $v$ Harbottle. ${ }^{2}$ However, following the realisation of intolerable deficiencies in the common law, ${ }^{3}$ the United Kingdom Law Commission (the Law Commission) recommended that there should be "a new derivative procedure with more modern, flexible and accessible criteria for determining whether a shareholder can pursue the action". ${ }^{4}$ This recommendation stemmed from the Law Commission's consideration of the six guiding principles, namely the proper plaintiff rule, the internal management principle, the nature of commercial decisions, the sanctity of contract, freedom of company management from unnecessary shareholder interference and the efficiency and cost effectiveness of litigation. $^{5}$

Commenting on the current English company law regime, Davies and Worthington have asserted that one vital and innovative feature of the Companies Act (the Act) is that the "gatekeeping decision" whether or not to continue with derivative litigation has been placed in the hands of an outsider. ${ }^{7}$ That outsider is the court. Accordingly, subsequent to the initiation of a derivative suit, the court will usually exercise its discretion to either refuse or grant permission for the suit to continue. ${ }^{8}$ Leave of the court refers

Friedrich Hamadziripi. LLB (cum laude) LLM LLD (UFH). Part-time Lecturer, Nelson R Mandela School of Law, University of Fort Hare, South Africa. Email: FHamadziripi@ufh.ac.za. ORCiD: https://orcid.org/0000-0002-7034-1279.

** Patrick C Osode. LLB BL LLM SJD. Professor, Department of Mercantile Law, Nelson R Mandela School of Law, University of Fort Hare, South Africa. Email: POsode@ufh.ac.za. ORCiD: https://orcid.org/0000-0002-8671-2484.

$1 \quad$ Zouridakis Shareholder Protection Reconsidered 4; Keay 2016 JCLS 40.

2 Foss $v$ Harbottle (1843) 67 ER 189. The requirement of wrongdoer control or fraud on the minority is what came to be known as the rule in Foss $v$ Harbottle. Also see Cassim et al Contemporary Company Law 775.

3 See UK Law Commission Shareholder Remedies Consultation Paper paras 14.114.4; Jailani 2018 UCL J L \& J 74.

$4 \quad$ UK Law Commission Shareholder Remedies Report para 6.15. Also see GibbsKneller and Ogbonnaya 2019 JCLS 304; Keay 2016 JCLS 40.

$5 \quad$ UK Law Commission Shareholder Remedies Report para 1.9. Also see Cinematic Finance Ltd v Ryder [2012] BCC 797 para 11.

Companies Act, 2006 (the Act).

Davies and Worthington Gower's Principles of Modern Company Law 598; Keay 2016 JCLS 40.

8 Davies and Worthington Gower's Principles of Modern Company Law 598; Cassim 2013 SALJ 497. 
to the permission obtained from a court to take some action which would not be allowed without such approval. ${ }^{9}$ Alternatively, it can simply be defined as judicial authorisation to follow a non-routine procedure..$^{10}$ Accordingly, in the context of the discussion undertaken in this article, leave of the court refers to the court's prerogative to allow or prevent the commencement or continuation of derivative proceedings.

It is trite that a shareholder ${ }^{11}$ or indeed any suitable stakeholder ${ }^{12}$ may initiate derivative litigation. In the UK, derivative actions may be brought either in terms of Chapter 1 of Part 11 of the $\mathrm{Act}^{13}$ or pursuant to an order of court granted in proceedings under section 994 of the same Act. The primary purpose of the requirement of leave of court is to provide a filter against unmeritorious actions. ${ }^{14}$ Other secondary purposes or by-products of this judicial discretion include limiting strike suits and greenmail. ${ }^{15}$ However, while it is accepted that the English legislature intended that the requirement of the leave of court be instrumental in filtering out vexatious and frivolous derivative suits, it must be noted that in practice, the same requirement may manifest as an insurmountable hurdle for honest derivative litigants. ${ }^{16}$ This article examines the attitude of English courts towards the application and interpretation of the criteria for the granting of leave to pursue derivative actions directed at violations of directors' duties.

The effectiveness of legislative regulatory devices generally and commercial law-related instruments in particular may to a greater extent depend on judicial interpretation and application. ${ }^{17}$ The adoption of a conservative and literal interpretive approach that is "purpose-neutral" will significantly undermine the prospects of the current derivative remedy regime achieving the policy objectives intended by the law and

Garner et al Black's Law Dictionary 910.

Garner et al Black's Law Dictionary 910.

With respect to the UK, see s 261(1) of the Companies Act, 2006. The practical effect of the contemporaneous ownership rule in the United States of America is that it effectively restricts derivative standing to shareholders as well. However, there have been calls to extend derivative standing to other stakeholders such as employees. See the discussion in Safari and Gelter 2019 JCLS 43-68.

In South Africa, s 165(2)(d) of the Companies Act 71 of 2008 extends derivative standing to any person to whom the court may grant leave only if the court is satisfied that it is necessary or expedient to do so to protect a legal right of that other person. The scope of South Africa's derivative scheme is very wide. See the discussion in Cassim et al Contemporary Company Law 779-792.

Gibbs-Kneller and Ogbonnaya 2019 JCLS 304; Jailani 2018 UCL J L \& J 73-74.

Baum and Puchniak "Derivative Action" 48; Cassim 2014 SA Merc LJ 7.

Cassim 2018 SALJ 107.

Hamadziripi Derivative Actions in Contemporary Company Law 293.

Osode 2015 Penn State JLIA 461. 
policymakers. ${ }^{18}$ To that end, several English court decisions handed down after the enactment of the 2006 Act and spanning over a period of approximately ten years are examined. Ultimately it is considered whether the leave requirement in English derivative litigation is proving to be an invaluable and indispensable procedural prerequisite or an implausible barrier to well-meaning litigants.

\section{The requirement of the leave of court in context}

Statutory derivative claims in the UK are governed by the provisions of sections 260 to 264 of the Act. These provisions establish a two-stage procedure for obtaining permission to bring such claims. ${ }^{19}$ The first stage, as set out in section 261(2) of the Act, is essentially an ex parte procedure. ${ }^{20}$ If it appears to the court that the application and the evidence filed by the applicant in support of it disclose a prima facie case, the claim will proceed to the second stage. ${ }^{21}$ This stage entails a hearing where the applicant seeks permission to continue the claim in the name and on behalf of the company. ${ }^{22}$ It is the role of the court at this second stage that is the focus of this contribution. Unlike other jurisdictions, ${ }^{23}$ the UK's derivative suits' procedure involves the court at an early stage. This allows the judiciary to effectively dismiss "unmeritorious claims [without] wasting corporate assets to defend frivolous claims." 24 Early judicial involvement affords the court, as an independent arbiter, the opportunity to separate frivolous claims from valid ones. ${ }^{25}$ established, then it must dismiss the application and may make any consequential order it considers appropriate.

22 Section 261(4) of the Act. Also see Keay 2016 JCLS 43.

23 For example, in South Africa and the United States of America (USA) the applicant is generally required to comply with the onerous and burdensome demand requirement. The position is worse in the USA, where a litigant's demand is handled by the controversial Special Litigation Committees. All this is done before one approaches the court. It has to be noted that there are some exceptional circumstances that warrant bypassing the demand requirement, but this does not make it easier for derivative applicants either. In the USA a derivative litigant who wishes to evade the demand requirement will have to comply with at least the equally notorious demand futility requirement. See ss 165(2)-(4) of the South African Companies Act 71 of 2008; Davis et al Companies and other Business Structures 297; the USA's Federal Rule of Civil Procedure 23.1; Cassim 2013 SA Merc LJ 314. Goehre 2010 Wisconsin Int'I LJ 158. Contemporary Company Law 21.
} 
The discretion has to be exercised according to established principles. Section 263 of the Act sets out the criteria which must be taken into account by the court in exercising its discretion to determine whether to grant permission to continue a derivative claim. ${ }^{26}$ It has been held that these provisions do not prescribe a particular standard of proof that has to be satisfied. Rather, the provisions require the consideration of a range of factors to reach an overall view. ${ }^{27} \mathrm{~A}$ reflective examination of the judicial attitude towards the current English derivative action provisions follows hereunder.

\section{Assessment of jurisprudence}

\subsection{Judicial articulation of the requirement of the mandatory refusal of permission}

One of the issues that has incessantly emerged before the English courts relates to the circumstances under which the judiciary is mandated to refuse permission to commence or continue derivative proceedings. Section 263(2) of the Act elaborates certain grounds on which the courts must refuse permission to continue a derivative suit. If the presence of any of the three prescribed factors is shown, then the court has no discretion in the matter: it must order immediate termination of the derivative litigation. ${ }^{28}$ The first such factor or ground arises where the court is satisfied that a person acting in accordance with the general duty of directors created in section

26 Great Britain Explanatory Notes note 498. In South Africa the extant company law is substantially similar in terms of the statutory role prescribed for judicial discretion. According to s 165(5)(b) of the South African Companies Act 71 of 2008, a court may grant leave to commence or continue derivative litigation only if it is "satisfied that the applicant is acting in good faith, [that] the proposed or continuing proceedings involve the trial of a serious question of material consequence to the company and [that] it is in the best interests of the company that the applicant be granted leave to commence the proposed proceedings or continue the proceedings." In the case of Lewis Group v Woollam 20172 SA 547 (WCC), it was held that the primary purpose for the requirement of leave of the court is to provide a filter against unmeritorious actions.

27 Stainer $v$ Lee [2010] EWHC 1539 (Ch) para 29. Also see Kleanthous $v$ Paphitis [2011] EWHC $2287(\mathrm{Ch})$ para 39, where it was held that there are no threshold requirements for a claim to be allowed to continue. In fact, a court can grant leave for a derivative claim to be continued without being satisfied that there is a strong case.

$28 \quad$ Franbar Holdings Ltd v Patel [2008] EWHC 1534 (Ch) 8. 
172 of the Act $^{29}$ would not seek to continue the claim. ${ }^{30}$ This has arguably been the most contentious of the three grounds for the mandatory judicial refusal of leave. ${ }^{31}$ In Franbar Holdings Ltd $v$ Patel, ${ }^{32}$ the plaintiff claimed that the first and second defendant directors diverted some business opportunities from the affected company, which was the third defendant. Consequently, the plaintiff commenced action under section 261 of the Act, seeking leave to institute derivative litigation to recover losses allegedly suffered by the company. ${ }^{33}$ It was held that the court is required to refuse permission only if it is satisfied that a hypothetical director acting in accordance with the general duty to promote the success of the company would not seek to continue the claim. ${ }^{34}$

The court adopted a liberal approach and noted that section 172 of the Act could be interpreted in more than one way. On the one hand, some directors might be convinced that the evidence before them was materially sufficient to conclude that the conduct complained of gave rise to actionable breaches of duty. On the other hand, some directors might wish to spend more time investigating the complaint before issuing process. ${ }^{35}$ The court must be applauded for impliedly holding that a derivative applicant does not

29 Section 172 of the Companies Act, 2006 lists some of the factors to be taken into account by a director of a company when acting in what s/he considers, in good faith, would most likely promote the success of the company for the benefit of its members as a whole.

30 Section 263(2)(a) of the Companies Act, 2006. S 172(1) of the UK Companies Act states that a person acting to promote the success of the company must have regard to "the likely consequences of any decision in the long term, the interests of the company's employees, the need to foster the company's business relationships with suppliers, customers and others, the impact of the company's operations on the community and the environment, the desirability of the company maintaining a reputation for high standards of business conduct, and the need to act fairly as between members of the company." Similarly, according to s 165(5)(b)(iii) of the South African Companies Act 71 of 2008, the court may grant leave only if it is satisfied that "it is in the best interests of the company that the applicant be granted leave to commence the proposed proceedings or continue the proceedings, as the case may be."

31 The other two grounds for the mandatory refusal of permission are instances where the cause of action arises from conduct that is yet to occur, or where the act or omission has been authorised by the company and where the cause of action arises from conduct that has already occurred, which was either authorised by the company before it occurred or was ratified afterwards. See s 263(2)(b) and (c) and the discussion by Hamadziripi Derivative Actions in Contemporary Company Law 339344.

$32 \quad$ Franbar Holdings Ltd v Patel [2008] EWHC 1534 (Ch) para 11.

$33 \quad$ Franbar Holdings Ltd v Patel [2008] EWHC 1534 (Ch) para 24.

$34 \quad$ Franbar Holdings Ltd v Patel [2008] EWHC 1534 (Ch) para 29. Also see Stimpson v Southern Private Landlords Association [2009] EWHC 2072 (Ch) para 22. Franbar Holdings Ltd v Patel [2008] EWHC 1534 (Ch) para 30. 
necessarily need to particularise the losses being claimed. ${ }^{36}$ Further, even though the applicant may fail to prove the allegations at trial, this possibility should not trigger mandatory refusal of permission by the judiciary. ${ }^{37}$ The court's decision in this case is salutary as it advances one of the legislature's policy aspirations, namely flexible and accessible criteria for determining whether a shareholder should be allowed to pursue the action on the company's behalf.

The English courts have also been asked to clarify the meaning of section 263(2)(a) of the Act. ${ }^{38}$ The provision refers to "a person", denoting singularity. However, not many companies have one director. Consequently, it is necessary for the courts to reconcile section 263(2)(a) with instances where a company's board consists of more than one director. In Kleanthous $v$ Paphitis ${ }^{39}$ it was held that the provisions of section 263(2)(a) would not be applicable simply because some or most of the directors would not seek to pursue the derivative claim. ${ }^{40}$ The most contentious decision on section 263(2)(a) was handed down by Roth $\mathrm{J}$ in Stainer $v$ Lee, ${ }^{41}$ where it was held that the mandatory bar in section 263(2)(a) applies "only where the court is satisfied that no director acting in accordance with section 172 would seek to continue the claim. If some directors would, and others would not seek to continue the claim the case is one for the application of section 263(3)(b)."42

Whilst it is probable that the decision of Roth $\mathrm{J}$ promotes one of the policy considerations informing the new derivative scheme, namely the accessibility of the remedy, it is submitted that the same decision might have other unintended consequences. First, by tying section 263(2)(a), which is a ground for the mandatory refusal of permission, to section 263(3)(b), which is a discretionary provision, the court might have effectively converted the former and placed it on a discretionary footing. It is inconceivable that

Franbar Holdings Ltd v Patel [2008] EWHC 1534 (Ch) para 22. Franbar Holdings Ltd v Patel [2008] EWHC 1534 (Ch) para 30.

This section provides that "[p]ermission (or leave) must be refused if the court is satisfied that a person acting in accordance with s 172 (duty to promote the success of the company) would not seek to continue the claim."

Kleanthous v Paphitis [2011] EWHC 2287 (Ch).

Kleanthous v Paphitis [2011] EWHC 2287 (Ch) para 38.

Stainer v Lee [2010] EWHC 1539 (Ch).

Stainer $v$ Lee [2010] EWHC 1539 (Ch) para 28. The approach was also followed in lesini v Westrip Holdings Ltd [2009] EWHC 2526 (Ch) para 86 and Parry v Bartlett [2011] EWHC 3146 (Ch) para 75. S 263(3)(b) of the Act provides that in considering whether to give permission (or leave) the court must take into account in particular the importance that a person acting in accordance with $\mathrm{s} 172$ (duty to promote the success of the company) would attach to continuing it. 
boards of directors would always reach unanimous decisions. To that end, it is not implausible to argue that most board decisions on whether to pursue a wrong done to the company would leave some directors wishing to institute derivative proceedings whilst some may not. It is therefore submitted that the interpretation preferred by Roth $\mathrm{J}$ effectively leaves section 263(2)(a) with only two grounds of mandatory refusal of permission, which is clearly inconsistent with the legislative intent. Second, a corollary of the first consequence is that the decision set the mandatory refusal bar on a lofty pedestal for all derivative defendants, as it requires them to prove or convince the court that no person acting in accordance with section 172 would be opposed to a continuation of the claim. This may lead to the abuse of section 263(2)(a) by derivative applicants.

Another interesting issue pertaining to the interpretation of section 263(2)(a) relates to the nature of the company in question. Judicial wisdom from Stimpson $v$ Southern Private Landlords Association ${ }^{43}$ (SPLA) is vital in the context of derivative actions involving not-for-profit entities. Ordinarily the court's permission to commence or continue derivative litigation is usually sought in the context of trading companies that are limited by shares and whose members are shareholders. ${ }^{44}$ Contrary to the norm, the first defendant in Stimpson $v$ SPLA was a not-for-profit organisation limited by guarantee, whose members were described as "transient affiliates who are members only for so long as they pay their subscriptions." 45 One of the critical facts leading to the legal proceedings was that SPLA was involved in a merger agreement with the sixth defendant, pursuant to which the directors transferred its assets to the acquirer. The entity was primarily formed to represent the interests of private landlords inter alia by providing facilities such as insurance and mortgages for the benefit of its members through negotiating with commercial providers of such services. Members were members for each year for which they paid an annual subscription and if they failed to pay the subscription they ceased to be members one month after the subscription became due.

Clearly, what constitutes the "success" of a trading company that is limited by shares and whose members are shareholders has to be different from that of a non-profit making organisation limited by guarantee and whose membership is renewable every 12 months. The company's objects and members' benefits in these two entities will definitely differ. One is driven by

43 Stimpson v Southern Private Landlords Association [2009] EWHC 2072 (Ch) (Stimpson v SPLA).

$44 \quad$ Stimpson v SPLA [2009] EWHC 2072 (Ch) para 25.

$45 \quad$ Stimpson $v$ SPLA [2009] EWHC 2072 (Ch) para 25. 
profit maximisation whilst the other one seeks service provision. The court in Stimpson $v$ SPLA held that section 172(2) contemplates two different scenarios. First, where the objects of the company ${ }^{46}$ consist of purposes other than the benefit of its members and that where the purposes of the company include purposes other than the benefit of its members. ${ }^{47}$ Where there is a conflict between promoting the success of the company for the benefit of its members and the achievement of the other objectives, a balancing exercise would be required. ${ }^{48}$

Due to the uniqueness of the company in Stimpson v SPLA, the court also gave considerable weight to:

[T]he ability of the company to provide benefits to its members after completion of the litigation, the degree to which delay in completing the litigation would affect the ability of the company to provide services for its members at all, and the degree to which the company can expect to retain/regain members during/after the litigation, bearing in mind that the only income that the first defendant has ever had is its subscription income ${ }^{49}$

Given the context of the case, it was held that claims that the directors breached their duties by transferring its assets were invalid as the entity in question was not a trading company, but rather a not-for-profit service provider. ${ }^{50}$ Furthermore, the board acted in accordance with the company's general meeting resolution to effect a merger. The court reiterated the fact that the first defendant's members had no shares. Further, the court took into account the fact that under the new arrangement, the first respondent's members were to receive services which were at least equal to what they used to receive from the company. In addition to considering the realistic prospects of making a recovery, the court gave considerable weight to the issue of the costs of funding the litigation, taking into account that the first respondent's source of income was essentially membership subscriptions. ${ }^{51}$ After considering the company's reduced membership numbers and the risk of insolvency, the court held that a hypothetical director would not seek to continue the claim.

The court's decision Stimpson $v$ SPLA should be regarded as a valuable addition to the UK's jurisprudence pertaining to the leave of the court in derivative proceedings. Considering that the Act does not explicitly

As evident from the company's constitution.

Stimpson v SPLA [2009] EWHC 2072 (Ch) para 26.

Stimpson v SPLA [2009] EWHC 2072 (Ch) para 26.

Stimpson v SPLA [2009] EWHC 2072 (Ch) para 28.

Stimpson v SPLA [2009] EWHC 2072 (Ch) para 29.

Stimpson v SPLA [2009] EWHC 2072 (Ch) para 28. 
differentiate between for-profit and not-for-profit companies in the context of derivative litigation, it was insightful for the court to consider the divergence of interests between the two types of companies. Ordinarily, courts have been predisposed to accede to applicants' pleas in instances of the transfer of company assets. However, the court in Stimpson v SPLA departed from the traditional practice and correctly treated this unique case with the appropriate exceptional discretion it deserved, thereby promoting legal certainty.

In the controversial case of Parry $v$ Bartlett $t^{52}$ the court was again called to exercise its discretion on whether a derivative claim should continue on behalf of a dissolved company whose shareholding was equally split between the two contesting parties. To effectively pursue litigation, the applicant first successfully made an application to restore the company to the register of companies since it had not been struck off. The daily management of the company vested in the defendant-respondent who argued that permission for the derivative claim should be refused on the grounds that the applicant was seeking relief on behalf of a non-trading company, the impugned conduct was either ratified or at least ratifiable in terms of sections 263(3)(d) of the Act, and the applicant had an ulterior motive which displaced his good faith. ${ }^{53}$

The respondent contended that since the subject company was no longer trading, a hypothetical director acting in terms of section 172 would not consider inter alia its reputation, employees' interests, and its relationships with suppliers and customers. The only relevant consideration was to be found in section 172(1)(f), namely "the need to act fairly as between members of the company". In the circumstances, the applicant's argument that the claim would facilitate the return of a substantial amount of money to the company was upheld and therefore permission to proceed with it was granted by the court. This decision is a clear demonstration of how far the courts have gone to extend the boundaries of flexibility as a key policy consideration in the context of derivative proceedings. The decision in Parry $v$ Bartlett further exposed a significant deficiency in section 1 of the Act, which defines a company. That definitional provision makes reference to the formation and registration of a company but is silent on whether a nontrading entity can still be regarded as a company. Consequently, due to this

$52 \quad$ Parry $v$ Bartlett [2011] EWHC 3146 (Ch).

53 Hamadziripi Derivative Actions in Contemporary Company Law 320-322. 
gap the court "extended" the meaning of "company" in section 261(1) to include a non-trading company.

However, it can be argued that the rationality of the court's decision to stretch the meaning of the term "company" is debatable. If the subject company had been dissolved, the question is: whose interests did the applicant seek to protect? The underlying principle behind derivative litigation is the protection of the relevant company's interests, not related personal interests. ${ }^{54}$ While it is trite that the general effect of an administrative ${ }^{55}$ or judicial ${ }^{56}$ order of restoration to the register is that the company is deemed to have continued in existence as if it had not been dissolved or struck off the register, it is also noteworthy that in this case the restoration application was not made to enable the company to continue operating as a going concern. Although it was clear that the applicant's interests might have been violated during the existence of the company, it did not necessarily follow that the dispute had to be settled by means of a derivative remedy. It is submitted that the court in Parry $v$ Bartlett erred and that the factor of the interests of justice was arbitrarily stretched. The applicant should have had recourse in equity. The decision might set a wrong precedent leading to the abuse of the remedy by aggrieved persons with personal claims.

Conversely, South African law does not have a similar provision that mandates courts to refuse permission to commence or continue derivative litigation upon proof of certain factors. To this end, it is submitted that South African law is advanced in this regard and that the UK can learn some lessons from South Africa in this regard, such as minimising such judicial inconsistency as is evident from the decision of Roth $\mathrm{J}$ in Stainer $v$ Lee discussed above.

\subsection{The place and importance of good faith}

In considering whether to grant permission to a derivative applicant, an English court is required to consider whether the applicant or claimant is acting in good faith in seeking to pursue the claim. ${ }^{57}$ Proof of an ulterior motive in the institution of derivative litigation may be a sign of the claimant's

\footnotetext{
54 See Hamadziripi Derivative Actions in Contemporary Company Law 29-30 and the authorities referred to.

See s 1028 of the Act.

See $\mathrm{s} 1032$ of the Act.

Section 263(3)(a) of the English Companies Act, 2006.
} 
bad faith ${ }^{58} \mathrm{~A}$ derivative litigant who institutes action in bad faith risks being refused permission to continue with an application under section 261 of the Act. ${ }^{59}$ However, bare and unsubstantiated allegations are insufficient to prove bad faith. For example, the mere rejection of a buy-out offer by the applicant does not in itself extinguish her/his good faith. ${ }^{60}$ One has to prove that the offer was in such a form that its refusal provides credible evidence of a lack of good faith. ${ }^{61}$

While refusing the applicant permission in Stimpson $v S P L A,{ }^{62}$ the court held that the defendant directors acted in good faith because the impugned conduct was more beneficial to the company and the applicant did not attempt to show why the challenged action was "not substantially in the best interests of the members". ${ }^{63}$ In this case, the applicant's good faith was questioned based on his failure to first invoke the available internal remedies. ${ }^{64}$ This decision may potentially result in mixed fortunes for both derivative applicants and respondents. First, the court should be applauded for refusing permission where the impugned management conduct was beneficial to the company. It is submitted that this is a reasonable limitation to the right to access to derivative litigation. The limitation is consistent with the Law Commission's guiding principles, namely the proper plaintiff rule, the internal management principle, respect for directors' commercial decisions, and the freedom of company management from unnecessary shareholder interference. Clearly, the court's decision advances the policy goals behind the UK's statutory derivative action procedure.

$58 \quad$ In Australia the good faith requirement is provided for in $\mathrm{s} 237$ of the Corporations Act, 2001. As held in Swansson v RA Pratt Properties (Pty) Ltd 200242 ACSR 313, a court must have regard to two interrelated factors. The first is whether the applicant honestly believes that a good cause of action exists and that there are reasonable prospects of success. The second is whether the derivative action is brought for an ulterior motive which amounts to abuse of process. This approach was adopted by a South African High Court in Mouritzen v Greystones Enterprises (Pty) Ltd 20125 SA 74 (KZD). However, the approach was rejected by the Supreme Court of Appeal in Mbethe $v$ United Manganese of Kalahari (Pty) Limited 20176 SA 409 (SCA). Also see Cassim et al Contemporary Company Law 785; Hamadziripi 2018 JCCLP 74. Franbar Holdings Ltd v Patel [2008] EWHC 1534 (Ch) 10; Hamadziripi Derivative Actions in Contemporary Company Law 322-323.

$60 \quad$ Franbar Holdings Ltd $v$ Patel [2008] EWHC 1534 (Ch) 10.

$61 \quad$ Franbar Holdings Ltd v Patel [2008] EWHC 1534 (Ch) 10.

62 Stimpson v SPLA [2009] EWHC 2072 (Ch).

$63 \quad$ Stimpson $v$ SPLA [2009] EWHC 2072 (Ch) para 43.

64 Stimpson v SPLA [2009] EWHC 2072 (Ch) para 44. In that case, the claimant failed to attend board meetings to argue his case. Also, no request was made for an extraordinary general meeting in which the claimant could have moved to replace the current board. 
However, the court's reference to the applicant's failure to show why the impugned conduct was not "substantially" in the company's best interests could be confusing. What is the difference between conduct that is beneficial to the company and that which is substantially in its interest? How is the court to determine conduct that is substantially in the best interests of the company? It is noteworthy that the major reason for the failure of the common law derivation action regime was the vagueness of apparently simple terms such as the meaning of "control" in relation to wrongdoer control. ${ }^{65}$

In Stainer $v L^{2} e^{66}$ the court dismissed allegations that the applicant for permission to pursue derivative proceedings was acting in bad faith, concluding that his conduct in formally seeking and obtaining the support of thirty-five other minority shareholders was evidence that he was acting in good faith ${ }^{67}$ However, it is arguable that the court confused good faith with personal interest. Seeking and obtaining the support of other shareholders might reflect more of one's disinterestedness and less of her/his good faith. The term "good faith" means "[a] state of mind consisting in honesty in belief or purpose...".68 It is submitted that this case exhibits judicial misapprehension in failing to accept that there are instances when a director could act in good faith for the company's success whilst pursuing other objects. ${ }^{69}$ The implications of such a precedent may be devastating. In future a shareholder acting with ulterior motives may pass the "good faith" muster with ease by simply obtaining the support of other shareholders. The fact that the supporting shareholders offered their support in good faith does not necessarily mean that the "lead suitor" who initiated the derivative proceedings was also acting in good faith. Good faith cannot be imputed, as it pertains to an individual's state of mind. ${ }^{70}$ It is therefore submitted that the decision in Stainer $v$ Lee could inadvertently lead to the abuse of the derivative remedy in the UK. This is inconsistent with the proper plaintiff rule and the need for the freedom of company management from unnecessary shareholder interference.

65

Jailani 2018 UCL $J L \& J 76$. Under the abolished common law derivative regime, an aggrieved party had to prove that the impugned conduct was committed by those who controlled the company and therefore would not allow the company to sue.

Stainer v Lee [2010] EWHC 1539 (Ch).

Stainer v Lee [2010] EWHC 1539 (Ch) para 49.

Garner et al Black's Law Dictionary 701. Also see Hamadziripi Derivative Actions in Contemporary Company Law 310-311.

Cassim 2013 SALJ 516; Hamadziripi Derivative Actions in Contemporary Company Law 304-305.

Garner et al Black's Law Dictionary 701. 
On the other hand, it can also be argued that Stainer $v$ Lee was simply a reflection of the jurisprudence at the time the case was decided. Previously there had been two contrasting views. The first view had been concerned with actions instituted for the benefit of the company whilst the other perspective had related to actions brought for some other purpose.$^{71}$ Neither of these views had considered a scenario in which a claim was brought partly for the benefit of the company and partly for other reasons. ${ }^{72}$ This lacuna was addressed by Lewison $\mathrm{J}$ in lesini $v$ Westrip Holdings $L t d .^{73}$ In this case the respondents argued that the applicants' standing should be displaced for want of good faith. In its decision the court noted that an application brought in bad faith is liable to be struck out as an abuse of process. ${ }^{74}$ Concluding that the claim was brought in good faith, the court constructed a "dominant purpose" test accompanied by a "but-for" standard. By "dominant" is implied that there are other but inferior purposes. The dominant purpose should be the benefit of the company. The opponents of the derivative suit have to satisfy the court that "but for the collateral purpose, the claim would not have been brought. ${ }^{.75}$

The judgment of Lewison $\mathrm{J}$ in lesini $v$ Westrip Holdings is a welcome development as it is an acknowledgement that derivative claims may be commenced for ulterior motives. It follows that the mere presence of an inferior ulterior motive is no longer an absolute bar to the institution of derivative proceedings in the UK. Consequently, the court's decision is consistent with the dictates of a flexible and accessible derivative remedy. ${ }^{76}$

In South African derivative litigation, the plaintiff bears the onus to prove, on a balance of probabilities ${ }^{77}$ that $\mathrm{s} / \mathrm{he}$ is pursuing the purported derivative action in good faith. The presence of good faith cannot be presumed ${ }^{78}$ and there is no evidentiary burden on the respondent to disprove the applicant's good faith. ${ }^{79}$ In Mouritzen $v$ Greystones Enterprises (Pty) Ltd ${ }^{80}$ the court

\footnotetext{
71 For example, see Nurcombe v Nurcombe [1985] 1 WLR 370; and Barrett v Duckett [1995] BCC 362. derivative in nature as it contained no allegation of breach of duty by a director. The standard of proof remains the same for civil proceedings. No lower threshold is acceptable as was contended by the applicant's counsel in Mbethe $v$ United Manganese of Kalahari (Pty) Ltd 20165 SA 414 (GJ) para 153. Mbethe v United Manganese of Kalahari (Pty) Ltd 20165 SA 414 (GJ) para 167. Mbethe $v$ United Manganese of Kalahari (Pty) Ltd 20165 SA 414 (GJ) para 174. 20125 SA 74 (KZD).
} 
held that although personal animosity between two opposing parties "is an important factor which the Court will always take into account together with other relevant evidentiary material", it was not, by itself, sufficient proof that a person referred to in sections 165(2) or 165(5) of the South African Companies Act was not acting in good faith. ${ }^{81}$

\subsection{Effect of the availability of an alternative remedy}

One of the issues that has received considerable judicial attention in the UK is the question of whether the availability of an alternative remedy is an absolute bar to permission to continue with a derivative claim. Notably, this issue may arise only in respect of the same acts and/or omissions. ${ }^{82}$ In Franbar Holdings Ltd $v$ Patel the court refused to grant permission to the plaintiff and held that "the availability (and indeed use) of both the section 994 petition $^{83}$ and the shareholders' action ${ }^{84}$ weigh in the balance against the grant of permission to continue the derivative action." 85 It is vital to note that in the said case, section 994 proceedings had already commenced. ${ }^{86}$ Hence, the court expressed the opinion that instituting another set of proceedings in the form of derivative litigation would cause future complexities. ${ }^{87}$ Furthermore, the court also gave considerable weight to the fact that the claimant was capable of achieving all that it wanted through the section 994 petition. ${ }^{88}$ Therefore, it is submitted that an English court will most likely refuse permission to continue a derivative claim if such a refusal does not limit the claimant's rights or result in unfair prejudice to her/his interests.

Another interesting issue arose in Bamford $v$ Harvey. ${ }^{89}$ The plaintiff and defendant (Harvey) were the sole directors of the company and also held

81

82

83

84

87

88

89

Mouritzen v Greystones Enterprises (Pty) Ltd 20125 SA 74 (KZD) para 59.

Franbar Holdings Ltd v Patel [2008] EWHC 1534 (Ch) para15.

According to s 994(1) of the UK Companies Act: "A member of a company or a person who is not a member of a company but to whom shares in the company have been transferred or transmitted by operation of law may apply to the court for an order on the ground that the company's affairs are being or have been conducted in a manner that is unfairly prejudicial to the interests of members generally or of some part of its members (including at least himself), or that an actual or proposed act or omission of the company (including an act or omission on its behalf) is or would be so prejudicial."

Shareholders' actions are brought in terms of ss 370 and 371 of the UK Companies Act with specific regards to the liability of directors in case of unauthorised donation or expenditure.

Franbar Holdings Ltd v Patel [2008] EWHC 1534 (Ch) para 15.

Franbar Holdings Ltd v Patel [2008] EWHC 1534 (Ch) para 16.

Franbar Holdings Ltd v Patel [2008] EWHC 1534 (Ch) para 17.

Bamford $v$ Harvey [2012] EWHC 2858 (Ch). 
$50 \%$ apiece of the company's issued share capital. Surprisingly, the objection to the derivative claim was not based on any of the grounds in section 263(2) or (3) of the Act. It was contended on behalf of the defendant that the court should reject the plaintiff's claim since "there was a mechanism whereby [the applicant] could procure that the company brings ordinary proceedings against him." 90 The respondent's argument was based on the shareholders' agreement according to which Harvey contended that the company could bring proceedings against him and that he would not have prevented it from doing so. ${ }^{91}$ The court upheld the respondent's argument and refused permission. It was held that the proceedings could have been brought in the name of the company, which was the proper plaintiff, ${ }^{92}$ and there was no express objection to that. ${ }^{93}$ In the court's view, only in exceptional circumstances may a member maintain such proceedings on behalf of the company. ${ }^{94}$

The decision in Bamford $v$ Harvey adds value to the existing English derivative litigation jurisprudence. First, by upholding the respondent's argument the court demonstrated its willingness to consider any reasonable ground upon which permission may be refused. Judicial discretion is not, therefore, limited only to a consideration of the section 263(3) factors. ${ }^{95}$ Also, the decision reveals the importance and fundamental judicial desire to give effect to the principle of the sanctity of contract, which in casu was the shareholders' agreement. It is trite that the proper plaintiff rule required derivative proceedings to be treated as the exception rather than the norm. ${ }^{96}$

In Stainer $v$ Lee it was held that since the availability of an alternative remedy is included under section 263(3) of the Act and not under section $263(2$,$) it follows that it is a discretionary consideration and not an absolute$ bar to the granting of permission to proceed with a derivative claim. ${ }^{97}$ Simply put, if the legislature intended the availability of an alternative remedy to be an absolute bar, it should have included it among the factors for the mandatory refusal of leave. It is noteworthy that in the same case, Roth $\mathrm{J}$ further held that it is common ground that the same cause of action could provide an appropriate basis for both an unfair prejudice petition as well as

Bamford $v$ Harvey [2012] EWHC 2858 (Ch) para 6.

Bamford $v$ Harvey [2012] EWHC 2858 (Ch) para 20.

Keay 2016 JCLS 39, Zouridakis Shareholder Protection Reconsidered 3.

Bamford v Harvey [2012] EWHC 2858 (Ch) para 25.

Cassim et al Contemporary Company Law 775.

Hamadziripi Derivative Actions in Contemporary Company Law 299-300.

Tsang 2019 Vand J Transnat'I L 79.

Stainer v Lee [2010] EWHC 1539 (Ch) para 50. 
a derivative action. ${ }^{98}$ In such circumstances the court should, according to the learned judge, consider both the nature of the relief sought and the appropriate relief. $^{99}$ The theoretical availability to the applicant of proceedings by way of an unfair prejudice petition is not a reason to refuse permission. ${ }^{100}$ Permission was therefore granted to the applicant.

At the time when the case of Universal Project Management Services Ltd $v$ Fort Gilkicker $L t d^{101}$ was decided, the two issues raised therein had no precedent in any reported English authority. First, the application was brought in what is better known as a double derivative action. ${ }^{102}$ Second, the applicant was not a shareholder in the company in which the cause of action was allegedly vested. Rather, he was a member of a limited liability partnership $^{103}$ which owned all the shares in that company. This is in contrast to the traditional approach that shareholders are "the natural choice for the conferral of an extended locus standi to pursue a company's claim."104 Under the common law, courts were in exceptional cases prepared to confer locus standi upon one or more members of a holding company, where the holding company was itself subject to the same wrongdoer control as the company to which the derivative claim related. ${ }^{105}$ It was argued on behalf of the defendant respondent that the necessity of a derivative claim had not been demonstrated since the plaintiff had at its disposal two other "obvious alternative remedies". 106 One of these alternatives was an unfair prejudice petition. The court followed the approach in Stainer $v \operatorname{Lee}^{107}$ and granted permission for derivative

Stainer $v$ Lee [2010] EWHC 1539 (Ch) para 51.

Stainer $v$ Lee [2010] EWHC 1539 (Ch) para 51. It was further elaborated that, for example, a complaint for restitution based on unlawful conduct on the part of a director would be appropriately remedied by a derivative suit. Likewise, a petition to be bought out based on an unfair disregard of minority interests would be suitably addressed by $\mathrm{s} 994$ proceedings.

Stainer v Lee [2010] EWHC 1539 (Ch) para 52.

Universal Project Management Services Ltd v Fort Gilkicker Ltd [2013] EWHC 348 (Ch).

Alan and Lowry Company Law 194 are of the opinion that an action by a shareholder of a parent company on behalf of a subsidiary is called a double action, but if action is brought on behalf of a second-tier subsidiary, it is a triple derivative action. Collectively these are termed multiple actions.

Garner et al Black's Law Dictionary 1152.

Universal Project Management Services Ltd v Fort Gilkicker Ltd [2013] EWHC 348 (Ch) para 20 per Briggs J.

Universal Project Management Services Ltd v Fort Gilkicker Ltd [2013] EWHC 348

(Ch) para 21 while making reference to Wallersteiner $v$ Moir (No 2) [1975] 1 All ER 849; Halle v Trax BW Ltd [2000] BCC 1020; Trumann Investment Group v Societe General SA [2003] EWHC 1316 (Ch); and Airey v Cordell [2007] Bus LR 391.

Universal Project Management Services Ltd v Fort Gilkicker Ltd [2013] EWHC 348 (Ch) para 55.

Stainer v Lee [2010] EWHC 1539 (Ch) para 52. 
proceedings to continue. It held that the derivative remedy "was a single piece of procedural ingenuity, which did not distinguish between ordinary, multiple or double derivative actions" and was sufficiently flexible to accommodate applications by members of a parent company. ${ }^{108}$

This decision in Universal Project Management Services Ltd v Fort Gilkicker $L t d$ has far-reaching consequences. First, it was very bold and courageous of the court to uphold double derivative proceedings, about which the Act is silent. The judgment provides unequivocal confirmation that the 2006 Act did not abolish double or multiple derivative actions. ${ }^{109}$ Second, the decision is a further demonstration of how far the English courts are willing to go in the interests of justice to protect a company's assets. Also, it is submitted that the reference to "member of a company" in section 261(1) of the 2006 Act effectively includes a member of a holding company. It is further submitted that the court's liberal and flexible approach significantly enhances access to derivative proceedings.

In lesini $v$ Westrip Holdings Ltd ${ }^{110}$ the court also followed the decision in Stainer $v L^{2} e^{111}$ and dismissed the respondent's contention. It seems that the courts in the UK are not sympathetic to the view that a derivative remedy should be displaced by the mere theoretical availability of another remedy. The defendant so alleging should show cause why a section 994 petition is preferable to an application to pursue derivative proceedings under sections 261 or 262 of the Act. One such consideration which may tilt the scale in the defendant's favour is the company's potential costs liability. If an ordinary derivative suit is instituted, then the company will be liable to indemnify the claimant against her/his costs ${ }^{112}$ even if the claim is unsuccessful. ${ }^{113}$ However, if a section 994 petition is instituted, then the company will be only

\footnotetext{
108 Universal Project Management Services Ltd v Fort Gilkicker Ltd [2013] EWHC 348 (Ch) para 26.

109 See Tsang 2019 Vand J Transnat'l L 75 76; Hamadziripi Derivative Actions in Contemporary Company Law 122-123.

110 lesini v Westrip Holdings Ltd [2009] EWHC 2526 (Ch).

111 Stainer $v$ Lee [2010] EWHC 1539 (Ch) para 52.

112 This is in striking contrast to other comparable common law jurisdictions where a derivative claimant is not entitled to an automatic right of indemnification for costs. For example, s 242 of the Australian Corporations Act, 2001 empowers a court to exercise its discretion when making any costs order in relation to $s 237$ proceedings. A similar provision exists in s 165(10) and (11) of South Africa's Companies Act 71 of 2008. However, Cassim 2014 Merc LJ 15 argues on common law grounds that South African courts ought to award a derivative applicant an indemnification order once the court "grants leave or permission under s 165 save where the interests of justice or equity dictate otherwise."

113 lesini $v$ Westrip Holdings Ltd [2009] EWHC 2526 (Ch) para 124 while referring to Wallersteiner v Moir (No. 2) [1975] 1 All ER 849.
} 
a nominal party to the proceedings and therefore will not incur legal costs. ${ }^{114}$ Accordingly, the combination of a company's potential liability for litigation costs and the availability of an alternative remedy under section 994 present a strong case against the granting of leave. ${ }^{115}$

Lastly, in Parry $v$ Bartlett ${ }^{16}$ Behrens $\mathrm{J}$ fortified the established view that the existence of an alternative remedy is only a factor to be taken into account and is not an absolute and independent bar to the granting of the leave of the court. If the only other available remedy is a section 994 petition but the restrictions are such that the "remedy is precisely the same as is being sought in these proceedings, it would plainly be more proportionate to have a derivative claim now." 117 In any event, the alternative remedy must be a realistic one in the context of the facts of the case. ${ }^{118}$

Conversely, South African law does not require the courts to determine whether the availability of an alternative remedy precludes the granting of permission to continue with a derivative claim. However, some applicants appear to have been confused in deciding on whether to invoke the oppression remedy or derivative litigation, as is evident in Larrett $v$ Coega Development Corporation (Pty) Ltd. ${ }^{119}$

\section{Conclusion}

Although the above exposition does not cover all the English judicial decisions relating to the leave of the court for derivative actions handed down after the adoption and coming into effect of the 2006 Companies Act, it represents the current judicial attitude towards the exercise of judicial discretion in terms of section 263 of the Act. Also, the judicial decisions discussed above are the most oft-cited ones on the subject traversed in this article. After all has been said and done, it can be submitted that applicants who seek the court's permission for proceedings brought under section 261 of the Act face a mammoth task, as the courts have refused permission to prospective derivative litigants more often than they have granted it. For the said litigants, this judicial track record points to a success rate that is

\footnotetext{
$114 \quad$ lesini v Westrip Holdings Ltd [2009] EWHC 2526 (Ch) para 124.

115 lesini $v$ Westrip Holdings Ltd [2009] EWHC 2526 (Ch) para 126.

116 Parry v Bartlett [2011] EWHC 3146 (Ch) paras 89 and 91. However, for cases involving conduct that took place before 1 October 2007, the court must be satisfied that such an alternative remedy was not an absolute remedy under the old law. See para 90 of the same case.

$117 \quad$ Parry $v$ Bartlett [2011] EWHC 3146 (Ch) para 88.

118 Parry $v$ Bartlett [2011] EWHC 3146 (Ch) para 92.

119 Larrett $v$ Coega Development Corporation (Pty) Ltd (ECD) (unreported) case number 2639/2013 of 13 March 2015.
} 
discouragingly low. For law- and policymakers zealous to witness the operation of a flexible and accessible derivative remedy in contemporary English company law, this must be a major cause of concern.

Another reason, especially for English shareholders, to be worried about the paucity of successful derivative action case ${ }^{120}$ is that the low success rate may easily be interpreted as representing a judicial attitude that is generally hostile to or not supportive of the granting of the leave of court applications pertaining to derivative proceedings. This perception has a further detrimental domino effect in that it may potentially result in the underutilisation of the remedy due to the widespread belief that derivative actions are not worthwhile because of the low prospects of success. Considering the time, money and other resources that must of necessity be invested in derivative litigation, English shareholders might increasingly gravitate away from using the remedy if the success rate remains low. As has already been observed, more shareholders are increasingly opting for section 994 applications. ${ }^{121}$

Nevertheless, whilst it is a fact that most of the English decisions on derivative remedy-related applications for the leave of court under the 2006 Act have been negative, it is also noteworthy that "the rulings and interpretive positions they have taken on most of the pivotal questions and issues can be said to be [shareholder] friendly and therefore supportive of the future development of the mechanism." ${ }^{122}$ Cases that readily come to mind in this regard include Universal Project Management Services Ltd $v$ Fort Gilkicker Ltd ${ }^{123}$ and Parry $v$ Bartlett. ${ }^{124}$ It is submitted that the decisions handed down by the English courts in these cases are plausible. It is therefore hoped that such jurisprudential value-adding decisions will be followed in future.

\footnotetext{
$120 \quad$ Keay 2016 JCLS 44.

Keay 2016 JCLS 44.

Osode 2015 Penn State JLIA 488.

Universal Project Management Services Ltd v Fort Gilkicker Ltd [2013] EWHC 348 (Ch).

$124 \quad$ Parry v Bartlett [2011] EWHC 3146 (Ch).
} 


\section{Bibliography}

\section{Literature}

Alan and Lowry Company Law

Alan D and Lowry J Company Law: Core Texts and Series $8^{\text {th }}$ ed (Oxford University Press Oxford 2014)

Baum and Puchniak "Derivative Action"

Baum H and Puchniak DW "The Derivative Action: An Economic, Historical and Practice-oriented Approach" in Puchniak DW et al (eds) The Derivative Action in Asia: A Comparative and Functional Approach (Cambridge University Press Cambridge 2012) 1-89

Cassim et al Contemporary Company Law

Cassim FHI et al Contemporary Company Law $2^{\text {nd }}$ ed (Juta Claremont 2012)

\section{Cassim 2013 SALJ}

Cassim MF "The Statutory Derivative Action under the Companies Act of 2008: The Role of Good Faith" 2013 SALJ 496-526

Cassim 2013 SA Merc LJ

Cassim MF "When Companies are Harmed by their Own Directors: The Defects in the Statutory Derivative Action and the Cures (Part 2)" 2013 SA Merc LJ 301-322

Cassim 2014 SA Merc LJ

Cassim MF "Costs Orders, Obstacles and Barriers to the Derivative Action under s 165 of the Companies Act 71 of 2008 (Part 1)" 2014 SA Merc LJ 123

Cassim 2018 SALJ

Cassim MF "The Doctrine of Contemporaneous Share Ownership and Aspects of Locus Standi in the New Derivative Action" 2018 SALJ 101-120

Davis et al Companies and other Business Structures

Davis D et al Companies and other Business Structures in South Africa $3^{\text {rd }}$ ed (Oxford University Press Cape Town 2013)

Davies and Worthington Gower's Principles of Modern Company Law Davies PL and Worthington S Gower's Principles of Modern Company Law $10^{\text {th }}$ ed (Sweet and Maxwell Publishers London 2016) 
Garner et al Black's Law Dictionary

Garner BA et al Black's Law Dictionary $8^{\text {th }}$ ed (Thomson West St Paul 2004)

Gibbs-Kneller and Ogbonnaya 2019 JCLS

Gibbs-Kneller D and Ogbonnaya C "Empirical Analysis of the Statutory Derivative Claim: De Facto Application and the Sine Quibus Non" 2019 JCLS 303-332

Goehre 2010 Wisconsin Int'I LJ

Goehre KA "Is the Demand Requirement Obsolete? How the United Kingdom Modernized its Shareholder Derivative Procedure and What the United States Can Learn from It" 2010 Wisconsin Int'I LJ 140-169

Great Britain Explanatory Notes

Great Britian Explanatory Notes on the Companies Act of 2006 (HMSO London 2006)

Hamadziripi 2018 JCCLP

Hamadziripi F "Judicial Construction of the Requirement of Good Faith in $\mathrm{s}$ 165(5)(b) of the Companies Act 71 of 2008: Mbethe $v$ United Manganese of Kalahari" 2018 JCCLP 74-87

Hamadziripi Derivative Actions in Contemporary Company Law Hamadziripi $\mathrm{F}$ Derivative Actions in Contemporary Company Law: A Comparative Assessment from an Enhanced Accountability Perspective (LLD-thesis, University of Fort Hare 2020)

Jailani 2018 UCL J L \& J

Jailani Q "Derivative Claims under the Companies Act 2006: In Need of Reform" 2018 UCL J L \& J 72-100

Keay 2016 JCLS

Keay A "Assessing and Rethinking the Statutory Scheme for Derivative Actions under the Companies Act" 2016 JCLS 39-68

Osode 2015 Penn State JLIA

Osode PC "Judicial Implementation of South Africa's New Business Rescue Model: A Preliminary Assessment" 2015 Penn State JLIA 459-488

Safari and Gelter 2019 JCLS

Safari N and Gelter M "British Home Stores Collapse: The Case for an Employee Derivative Claim" 2019 JCLS 43-68 
Tsang 2019 Vand J Transnat'I L

Tsang KF "International Multiple Derivative Actions" 2019 Vand J Transnat'I $L 75-120$

UK Law Commission Shareholder Remedies Consultation Paper UK Law Commission Shareholder Remedies: Consultation Paper CP142 (HMSO London 1996)

UK Law Commission Shareholder Remedies Report

UK Law Commission Shareholder Remedies: Report LC246 (HMSO London 1997)

Zouridakis Shareholder Protection Reconsidered

Zouridakis G Shareholder Protection Reconsidered: Derivative Action in the UK, Germany and Greece (Routledge New York 2020)

\section{Case law}

Airey v Cordell [2007] Bus LR 391

Bamford v Harvey [2012] EWHC 2858 (Ch)

Barrett v Duckett [1995] BCC 362

Cinematic Finance Ltd v Ryder [2012] BCC 797

Foss $v$ Harbottle (1843) 67 ER 189

Franbar Holdings Ltd v Patel [2008] EWHC 1534 (Ch)

Goldsmith v Sperrings Ltd [1977] 1 WLR 478

Halle v Trax BW Ltd [2000] BCC 1020

lesini v Westrip Holdings Ltd [2009] EWHC 2526 (Ch)

Kleanthous v Paphitis [2011] EWHC 2287 (Ch)

Larrett $v$ Coega Development Corporation (Pty) Ltd (ECD) (unreported) case number 2639/2013 of 13 March 2015

Lewis Group v Woollam 20172 SA 547 (WCC)

Mbethe $v$ United Manganese of Kalahari (Pty) Ltd 20165 SA 414 (GJ) 
Mbethe $v$ United Manganese of Kalahari (Pty) Limited 20176 SA 409 (SCA)

Mouritzen v Greystones Enterprises (Pty) Ltd 20125 SA 74 (KZD)

Nurcombe $v$ Nurcombe [1985] 1 WLR 370

Parry v Bartlett [2011] EWHC 3146 (Ch)

Stainer v Lee [2010] EWHC 1539 (Ch)

Stimpson v Southern Private Landlords Association [2009] EWHC 2072 (Ch)

Swansson v RA Pratt Properties (Pty) Ltd 200242 ACSR 313

Trumann Investment Group v Societe General SA [2003] EWHC 1316 (Ch

Universal Project Management Services Ltd v Fort Gilkicker Ltd [2013] EWHC 348 (Ch)

Wallersteiner v Moir (No 2) [1975] 1 All ER 849

\section{Legislation}

Companies Act, 2006 (UK)

Corporations Act, 2001 (Australia)

Companies Act 71 of 2008 (SA)

Federal Rule of Civil Procedure 23.1 (USA)

\section{List of Abbreviations}

JCCLP

JCLS

Penn State JLIA

SALJ

SA Merc LJ

SPLA

UCL J L \& J
Journal of Corporate and Commercial Law and Practice Journal of Corporate Law Studies Penn State Journal of Law and International Affairs

South African Law Journal

South African Mercantile Law Journal Southern Private Landlords Association University College London Journal of Law and Jurisprudence 
UK

USA

Vand J Transnat'I L

Wisconsin Int'l LJ
United Kingdom

United States of America

Vanderbilt Journal of Transnational Law

Wisconsin International Law Journal 